\title{
Analisis Metode Penggalangan Intelijen Dalam Penerapan Program Deradikalisasi oleh BNPT
}

\section{Analysis of Intelligence Raising Methods in the Implementation of the Deradicalization Program by BNPT}

\author{
Ahmad Pradipta Budhihatma Adikara ${ }^{*}$, Muhammad Luthfi Zuhdi2 ${ }^{2}$, Wawan Hari Purwanto ${ }^{3}$ \\ Program Studi Kajian Ketahanan Nasional, Sekolah Kajian Stratejik \& Global, Universitas Indonesia \\ 1ahmad.pradipta@ui.ac.id*; 2m.luthfiz009@gmail.com; 3hp_wawan@yahoo.com \\ *Penulis koresponden
}

\begin{abstract}
Abstrak
Penyebaran paham radikalisme dan terorisme masih menjadi ancaman besar bagi bangsa Indonesia. Puluhan hingga ratusan orang ditangkap karena terlibat tindak pidana terorisme. Upaya deradikalisasi harus dilakukan sekrompehensif dan pendekatan selunak mungkin oleh Badan Nasional Penanggulangan Terorisme (BNPT) supaya dapat mereduksi perkembangan radikalisme dan terorisme. Penelitian ini bertujuan untuk mengetahui dan menganalisis bentuk dari program deradikalisasi yang dilakukan oleh BNPT. Metode yang digunakan dalam penelitian ini adalah kualitatif deskriptif dengan menggunakan analisis penggalangan intelijen. Teknik pengumpulan data yang dilakukan dalam penelitian ini adalah dengan wawancara narasumber dan studi literatur. Analisa dan pengolahan data dalam penelitian ini menggunakan model triangulasi data untuk memastikan keabsahan data yang didapatkan dari narasumber satu dengan lainnya dan dari studi literatur. Hasil penelitian ini menunjukkan bahwa program deradikalisasi yang dilakukan oleh BNPT baik yang ada di dalam lapas dan di luar lapas menggunakan penggalangan intelijen dengan metode RASCLS (Reciprocation, Authority, Scarcity, Commitment, Liking, Social Proof) dan MICE (Money, Ideology, Coercion, Ego) namun tidak secara keseluruhan. Metode Scarcity dan Coercion tidak digunakan dalam program deradikalisasi karena tujuan deradikalisasi adalah melakukan pembinaan, pendampingan, dan pemberdayaan dengan hati ke hati bukan untuk membuat target (narapidana terorisme dan mantan narapidana terorisme) menjadi susah dan dipaksa.
\end{abstract}

Kata Kunci: Deradikalisasi, terorisme, BNPT, penggalangan intelijen, RASCLS, MICE.

\begin{abstract}
The spread of radicalism and terrorism is still a big threat to the Indonesian people. Tens to hundreds of people were arrested for being involved in criminal acts of terrorism. Deradicalization efforts must be carried out as comprehensively and as gently as possible by National Counterterrorism Agency (BNPT) in order to reduce the development of radicalism and terrorism. This study aims to identify and analyze the form of the deradicalization program carried out by the BNPT. The method used in this research is descriptive qualitative using intelligence-raising analysis. Data collection techniques carried out in this study were interviewing sources and literature studies. Analysis and processing of data in this study uses a data triangulation model to ensure the validity of the data obtained from each other and from literature studies. The results of this study indicate that the deradicalization program carried out by the BNPT both inside and outside prisons uses intelligence-raising methods with RASCLS (Reciprocation, Authority, Scarcity, Commitment, Liking, Social Proof) and MICE (Money, Ideology, Coercion, ego) but not as a whole. The Scarcity and Coercion methods are not used in the deradicalization program because the purpose of deradicalization is to provide guidance, assistance, and empowerment with a heart, not to make targets (terrorism convicts and exterrorism convicts) difficult and forced.
\end{abstract}

(C) 2021 oleh Ahmad Pradipta Budhihatma Adikara, Muhammad Luthfi Zuhdi, Wawan Hari Purwanto.

Artikel ini terbuka untuk umum (open access) dan dapat didistribusikan sesuai dengan aturan di dalam Lisensi Creative Commons Attribution (CC BYNC) di https://creativecommons.org/licenses/by-nc-sa/4.0/. 
Keywords: Deradicalization, Terrorism, BNPT, Raising Intelligence, RASCLS, MICE.

\section{Pendahuluan}

Penyebaran paham radikalisme masih menjadi ancaman besar bagi ketahanan ideologi negara Indonesia. Adanya reformasi dengan terbukanya segala indormasi menyebabkan perkembangan radikalisme yang dulunya bersifat klandestin, sekarang sudah terang-terangan. Radikalisme yang muncul di Indonesia berbasis pada gerakan radikal agama yang banyak bergerak pada organisasi masyarakat dan kelompok jamaah. Ideologi yang mereka anut adalah Khilafah Islamiyah dan masing-masing kelompok memiliki cara tersendiri dalam memperjuangkannya.

Menurut penelitian dari Wahid Foundation \& CSIS (2017) mengatakan bahwa gerakan kelompok radikal terbagi menjadi dua tipologi yaitu radikalisme ideologi dan radikalisme tingkah laku. Kelompok yang memiliki tipe radikalisme ideologi seperti Hizbut Tahrir Indonesia. Kemudian kelompok yang memiliki tipe radikalisme tingkah laku seperti JI, MMI, JAT, JAD, MIT, FPI, dan lain-lain. Kesamaan dari kedua tipologi tersebut adalah sama-sama memandang bahwa ideologi Pancasila dan bentuk pemerintah Indonesia ini adalah keliru dan tidak sesuai dengan syariat Islam.

Jika kita menengok lebih jauh ke belakang, catatan sejarah mengenai radikalisme Islam di Indonesia telah menggeliat sejak kemerdekaan Indonesia. Keinginan mendirikan Negara Islam telah digaungkan dan diperjuangkan oleh kelompok Darul Islam yang dipimpin oleh Sekarmadji Maridjan Kartosoewirjo pada 7 Agustus 1949 di Garut Jawa Tengah. Kelompok radikal tersebut terus berkembang hingga saat ini dan terbagi dalam berbagai organisasi. Penulis mengelompokkan menjadi 3 kategori yaitu pertama kelompok Islam radikal lokal, kedua kelompok Islam radikal transnasional, dan ketiga kelompok Islam radikal teroris/jihadis. Masing-masing kelompok tersebut saat ini telah tersebar di seluruh penjuru Indonesia dan bergerak dengan caranya masing-masing.

Radikalisme merupakan sebuah gerakan keagamaan yang memiliki keinginan untuk mengubah seluruh tatanan politik dan sosial dengan menggunakan cara-cara kekerasan
(Robingatun 2017). Menurut Idris (2017), radikalisme muncul karena adanya empat kosong yaitu, kosong kantong, kosong perut, kosong hati, dan kosong pikiran. Ketika semuanya sudah mengalami kekosongan maka akan memunculkan sikap yang mengharapkan adanya perubahan terhadap status quo dengan menghancurkan keadaan semula dan mengganti dengan yang baru (Purwanto, 2012).

Berdasarkan data, sepanjang tahun 2020 Polri telah melakukan penangkapan 228 orang yang terlibat dalam kelompok radikal teroris dan melakukan tindak pidana terorisme (Adyatama, 2020). Sedangkan pada Bulan Januari 2021 hingga bulan Maret 2021 telah dilakukan penangkapan sejumlah 94 orang (Dirgantara, 2021). Dengan banyaknya aktor radikal teroris yang tertangkap, menambah kerja dari Badan Nasional Penanggulangan Terorisme (BNPT) untuk melakukan deradikalisasi. Pada bulan April 2021, sebanyak 34 narapidana terorisme di Lapas Gunung Sindur telah berhasil kembali dan melakukan ikrar setia kepada NKRI. Namun, masih banyak narapidana terorisme dan mantan narapidana terorisme yang masih belum berhasil dilakukan deradikalisasi. Hal tersebut menjadi tantangan yang harus dilakukan BNPT. Upaya deradikalisasi harus dilakukan sekrompehensif mungkin. Metode penggalangan intelijen merupakan salah satu metode efektif dalam menggalang napiter dan eks napiter supaya dapat kembali kepangkuan NKRI.

Penggalangan intelijen merupakan sebuah aktivitas atau metode yang dilakukan untuk memengaruhi target agar dapat mengubah Emosi, Sikap, Tingkah laku, Opini, dan Motivasi (ESTOM) dari target tersebut (Saronto, 2018). Tujuan dilakukannya penggalangan adalah untuk menciptakan suatu kondisi tertentu yang terarah dan terukur sehingga target dapat melakukan apa yang dikehendaki oleh penggalang. Sukarno (2011) menjelaskan bahwa ada tiga strategi penggalangan yang harus dilakukan agar rencana dapat berjalan lancar, antara lain pertama win the heart and the mind of the target, kedua, bring the target to our direction, dan ketiga menciptakan situasi 
yang kondusif. Target yang dituju dalam melakukan penggalangan ada 3 kelompok seperti, kelompok lawan yang menentang tujuan dari penggalang, kelompok netral yang tidak menentang dan tidak mendukung, dan kelompok sekutu yang mendukung supaya tidak terpengaruhi oleh kelompok lawan. Penggalangan intelijen yang dilakukan secara lunak menggunakan sarana-sarana seperti melakukan persuasi untuk menanamkan pemahaman baru kepada target (dialog, silaturahmi, seminar, workshop), memberikan bantuan secara materi kepada target, dan melakukan kegiatan propaganda (Sukarno, 2011).

Sarana penggalangan menurut (Saronto, 2018) mencakup pada pola, teknik, dan taktik penggalangan. Pola penggalangan merupakan arah yang dituju untuk membuat target mau untuk mengikuti kehendak dari penggalang. Pola yang dilakukan ada dua, yaitu pola peruasif (bersifat membina, mendampingi, mengembangkan) dan pola koersif (bersifat menceraiberaikan, melemahkan, dan mengadu domba sasaran). Teknik penggalangan terbagi menjadi tiga antara lain Perang Urat Syaraf (PUS), Propaganda, dan Sabotase. Perang Urat Syaraf (PUS) adalah kegiatan yang bertujuan untuk memengaruhi ESTOM lawan. Propaganda adalah komunikasi yang dilakukan secara sengaja untuk memengaruhi tingkah laku lawan. Sabotase adalah kegiatan yang bertujuan untuk merusak dan menghancurkan sasaran berupa instalasi, infrastruktur, dan lain-lain. Saronto (2018) juga menjelaskan teknik dalam melakukan penggalangan terdiri dari gerakan menarik, menekan, memutar balik, memecah belah, dan mengadu domba.

Salah satu pendekatan yang digunakan dalam penggalangan intelijen adalah dengan pendekatan RASCLS dan MICE (Penaflor, 2012). Pendekatan RASCLS dan MICE dipopulerkan oleh Robert Cialdini (2007) dan Randy Burkett (2013). RASCLS dan MICE merupakan akronim dari Reiprocation, Authority, Scarcity, Commitment, Liking, Social Proof dan Money, Ideology, Coercion, Ego. Burkett (2013) mengatakan, kunci utama dalam melakukan mendekatan RASCLS dan MICE yaitu pada penguasaaan motif dan psikologi lawan. Pendekatan ini lebih menekankan pada prinsip-prinsip persuasif, dan hati ke hati karena yang akan dikendalikan adalah ESTOM lawan.

Penelitian ini bertujuan untuk mengetahui bagaimana bentuk dari program deradikalisasi yang dilakukan oleh BNPT dengan menggunakan metode penggalangan intelijen. Diharapkan adanya penelitian ini mampu memberikan masukan, sumbangan pemikiran, dan menjadi rekomendasi bagi BNPT guna perbaikan program deradikalisasi yang dirasa masih kurang maksimal. selain itu penelitian ini dapat menjadi referensi bagi penelitian lainnya yang berkenaan dengan radikalisme dan deradikalisasi.

\section{Metode}

Penelitian ini menggunakan pendekatan kualitatif deskriptif dengan pisau analisis penggalangan intelijen. Karakteristik dalam penelitian kualitatif adalah dengan menggunakan berbagai metode untuk melakukan eksplorasi dalam memahami makna yang terkandung dalam permasalahan. Peneliti bidang intelijen Hank Prunckun (2010) mengatakan, penelitian intelijen umumnya menggunakan pendekatan kualitatif karena lebih memahami penjelasan sebab akibat secara lebih dalam. Teknik pengumpulan data yang dilakukan dalam penelitian ini adalah dengan wawancara narasumber dan studi literatur. Analisis dan pengolahan data yang digunakan menggunakan model triangulasi data untuk memastikan keabsahan data yang didapatkan dari narasumber satu dengan lainnya dan dari studi literatur. Proses yang dilakukan dalam melakukan penelitian ini adalah melalui pengumpulan data, reduksi data, penyajian data, dan memberikan kesimpulan.

\section{Hasil dan Pembahasan}

\section{Program Deradikalisasi yang dilakukan oleh BNPT}

Deradikalisasi adalah sebuah istilah yang diambil dari kata radikal, radikalisasi, radikalisme, dan radikal terorisme. Radikal merupakan sebuah pemikiran yang mendasar, mendalam dan mengakar. Radikal terbagi menjadi dua secara prosesnya yaitu radikal konstruktif dan radikal destruktif. Kelompok yang berada di dalam radikal destruktif akan cenderung memunculkan sifat-sifat yang keras, intoleran, dan bahkan sampai melakukan tindakan teror. Kelompok 
radikal terbagi menjadi lima kluster yaitu kelompok inti, militant, pendukung, simpatisan, dan masyarakat.

Agus Surya Bakti (2014) dalam bukunya yang berjudul Darurat Terorisme mengatakan, yang dimaksud kelompok inti merupakan pemimpin atau amir dari kelompok tersebut. Kelompok militant adalah orang yang dipersiapkan untuk menjadi calon pemimpin dan terlibat dalam aksi teror. Kelompok pendukung adalah orang yang mendukung pada kelompok inti dan militant dalam bentuk sumbangan dana, logistik, tenaga, dan lain-lain. Kelompok simpatisan adalah orang yang setuju dengan gagasan kelompok tersebut namun hanya membantu secara sukarela dan temporer. Kelompok terakhir adalah kelompok masyarakat yang dianggap netral dan berada diluar lingkaran.

Untuk mengidentifikasi kelompok radikal, BNPT membagi menjadi empat kriteria, yang pertama adalah intoleran, kedua adalah anti Pancasila, ketiga adalah anti NKRI, dan keempat adalah hate crime dengan memiliki pemahaman takfiri. Proses pengidentifikasian yang dilakukan oleh BNPT merujuk pada kriteria yang dituliskan oleh Moghaddam (2005), dia membagi lima kriteria orang menjadi radikal dan teroris. Pertama adalah orang yang merasakan ketidakadilan dan memilih untuk memperbaiki individu mereka. Kedua adalah orang yang merasakan ketidakpuasan namun tidak mampu memperbaiki dan mulai mencari target untuk disalahkan. Ketiga adalah orang yang mulai merencanakan melakukan tindakan kekerasan dan melakukan perekrutan kepada orang lain. Keempat adalah orang yang sudah memiliki pemikiran melawan mereka, dan pada fase ini biasanya orang tersebut akan menarik diri dari lingkungannya. Kelima adalah orang yang pada akhirnya terlibat langsung dalam aksi kekerasan.

Program deradikalisasi yang dilakukan diluar negeri memiliki fokus untu mencapai tujuan rehabilitasi dan menghentikan penyebarah paham radikalisme (Suarda, 2016). Seperti yang dilakukan oleh Arab Saudi memiliki strategi yang bernama Prevention Rehabilitation and Aftercare (PRAC), program ini secara umum menggunakan pendekatan lunak kepada napiter dalam konsep reformasi dan transformasi (Porges, 2014). Kemudian Inggris juga meluncurkan program CONTEST (the Governments Counter-Terrorism Strategy) dan strategi mengenai pencegahan (Pickering, 2014). Namun disatu sisi pendekatan deradikalisasi yang dilakukan oleh negara-negara lain seperti Prancis, Belanda, Spanyol, Inggris, dan Amerika Serikat lebih menekankan prinsip "konsentrasi" dan fokus pada pendekatan yang bersifat keamanan (Neumann, 2010).

Sementara itu di Indonesia, Prof Irfan Idris selaku Direktur Deradikalisasi BNPT mengatakan bahwa proses deradikalisasi merupakan transformasi berfikir, aksi, perilaku yang destruktif menuju pada pembentukan ide dan cara berfikir yang konstruktif, moderat, dan holistik. Tujuan dilakukan program deradikalisasi adalah untuk mengajak para napiter, keluarga, dan eks napiter untuk kembali kepada jalan yang benar sesuai aturan agama dan negara. Berdasarkan data yang ditemukan penulis melalui wawancara dengan narasumber, BNPT telah berhasil melakukan identifikasi dan deradikalisasi di 24 provinsi dengan 1.127 eks napiter.

Bagi BNPT, program deradikalisasi mengacu pada dua hal yaitu pelepasan diri (disengagement) dan de-ideologisasi (Indrawan \& Aji, 2019). Pelepasan diri yang dimaksud adalah upaya untuk mengubah perilaku seseorang untuk meninggalkan aturan-aturan lamanya. Sedangkan deideologisasi adalah upaya untuk mereduksi pemahaman secara ideologis atas doktrin-doktrin salah mengenai agama. Dalam melaksanakan program deradikalisasi, BNPT membagi menjadi dua lokus yaitu deradikalisasi dalam lapas dan deradikalisasi luar lapas.

- Deradikalisasi Dalam Lapas: menyasar kepada tersangka, terdakwa, terpidana, dan narapidana tindak pidana terorisme.

- Deradikalisasi Luar Lapas: menyasar pada mantan napiter yang telah bebas dan masih belum terderadikalisasi secara maksimal ketika masih dalam lapas.

Deradikalisasi dalam lapas dilakukan dalam empat tahapan antara lain Identifikasi, Rehabilitasi, Reedukasi, dan Reintegrasi sosial. Sedangkan deradikalisasi luar lapas terdiri dari tahapan identifikasi, Pembinaan 
Kewirausahaan, Pembinaan Wawasan Kebangsaaan, dan Pembinaan Wawasan Keagamaan. Menurut narasumber penulis Ardi Putra P (Analis Permasyarakatan bidang Deradikalisasi BNPT) mengatakan, Sumber Daya Manusia petugas dari BNPT yang melakukan program deradikalisasi berasal dari berbagai macam disiplin ilmu, namun harus mengerti dan dapat melakukan kegiatan-kegiatan intelijen seperti memahami intelligence cycle, pengumpulan bahan keterangan, dan mampu melakukan intervensi kepada napiter/eks napiter yang sifatnya adalah penggalangan dan penyelidikan.

Dalam melakukan program deradikalisasi, tahapan pertama yang dilakukan oleh BNPT adalah identifikasi. Tahapan identifikasi dilakukan baik ketika masih di dalam lapas maupun ketika sudah di luar lapas. Dalam melakukan tahapan identifikasi, petugas menggunakan pendekatan kualitatif berupa wawancara dan observasi kepada napiter/eks napiter. Untuk mengukur tingkat radikal dari napiter/eks napiter BNPT menyebutnya sebagai AKURAT (Alat Ukur Radikalisme dan Terorisme). Pengukuran dilakukan dengan melihat ESTOM dari napiter/eks napiter. Tahap identifikasi wajib dilakukan oleh BNPT karena sasarannya adalah hal yang tidak "Nampak" yaitu ideologi dan pemikiran. Identifikasi dilakukan secara intensif dan terus menerus selama tiap bulan sekali dilakukan pengukuran. Dalam melakukan pengukuran, BNPT membagi menjadi 4 level, level pertama adalah orang yang masih sulit untuk didekati, level kedua adalah orang yang sudah bisa didekati namun belum bisa untuk dilakukan pembinaan, level ketiga adalah orang yang sudah bisa didekati, dilakukan pembinaan, namun masih belum dapat dipublikasikan, level keempat adalah orang yang sudah bisa diidentifikasi, dilakukan pembinaan, dan sudah bisa dipublikasikan.

Program deradikalisasi dalam lapas sangat membutuhkan upaya yang sangat sistematis dan komprehensif, karena jika tidak pada program lanjutan di luar lapas akan lebih sulit untuk dilakukan intervensi dan pembinaan. Tahap pertama adalah identifikasi, seperti yang sudah penulis paparkan diatas, hasil dari tahapan identifikasi menurut PP Nomor 77 Tahun 2019 Pasal 33 ayat 2 meliputi pertama identitas tersangka, kedua, profil psikologis terkait motivasi, persepsi, identitas, dan tingkat keterpaparan, ketiga keterlibatan peran dalam kelompok/organisasi/jaringan terorisnya, keempat adalah rekomendasi untuk tahapan selanjutnya.

Tahap rehabilitasi merupakan tahapan lanjutan setelah napiter dilakukan identifikasi. Dalam tahapan ini sasaran dari programnya adalah napiter dan keluarga napiter yang masih memiliki paham radikal. Dalam melakukan rehabilitasi terdapat dua program pembinaan, yaitu pembinaan kemandirian dan pembinaan kepribadian. Pembinaan kemandirian bertujuan untuk mempersiapkan para napiter agar memiliki ketrampilan dan keahlian paska mereka dinyatakan bebas. Program ini dilakukan dengan mendata serta mengelompokkan para napiter sesuai dengan keahlian dan ketrampilan kerjanya. Setelah dikelompokkan, para napiter dibagi sesuai keahlian dan keterampilannya seperti penjahitan, pengelasan, perkayuan, pertanian, perikanan, dan lain-lain (Febriyansah, Khodriah, Wardana, 2018). Kemudian program pembinaan kepribadian dilakukan dengan metode pendekatan secara dialog dengan tujuan menyentuh hati napiter. Bentuk program yang dilakukan berupa konseling individu, ceramah, diskusi, seminar, sosialisasi, pendampingan, dan lainlain. BNPT bekerja sama dengan DirjenPas untuk mendatangkan ahli agama, ahli psikologi, eks napiter yang sudah sadar, mantan pemimpin mereka di jaringannya, dan lain-lain.

Setelah para napiter direhabilitasi, tahapan selanjutnya adalah reedukasi. Tahap reedukasi merupakan penggalangan lanjutan kepada napiter yang dianggap telah berhasil melalui tahap rehabilitasi. Reedukasi dilakukan dengan memberikan pencerahan kepada napiter untuk menyadarkan pemahaman dan ideologi mereka yang menyimpang. Tahapan ini hampir sama dengan pembinaan kepribadian, namun pada tahap ini lebih fokus terhadap pendidikan moral napiter. Salah satu program yang dilakukan adalah dengan menggunakan konsep "hijrah" yang mengajak napiter meninggalkan kehidupan terdahulu mereka dan fokus menatap masa depan yang lebih nyata (Golose, 2009). 
Tahapan terakhir dalam program deradikalisasi dalam lapas adalah tahap reintegrasi sosial. Tahap ini merupakan tahapan yang paling penting dalam program deradikalisasi dalam lapas, karena paska bebas para napiter harus menjalani kehidupan bermasyarakat. Tanpa adanya pembinaan dan pendampingan selama proses menuju bebas, napiter pasti akan mendapatkan kesulitan untuk bisa diterima dimasyarakat. Terdapat beberapa kasus masyarakat yang menolak hadirnya eks napiter di kampungnya karena takut terstigma sebagai kampung teroris. Selain itu beberapa napiter yang tidak maksimal dilakukan pendampingan mengalami kesulitan dalam mencari kerja karena adanya "stampel" mantan narapidana terorisme. Merespon hal tersebut, dalam tahapan reintegrasi sosial, BNPT menyediakan pendistribusian berdasarkan ketrampilan dan kemampuan napiter paska bebas. Keluarga dan warga sekitar juga diberikan sosialisasi oleh BNPT supaya bisa menerima dengan baik para napiter yang akan bebas. Tujuan dari tahap reintegrasi sosial adalah membuat napiter bisa kembali dan diterima oleh masyarakat sehingga mampu memulihkan dirinya dan menjauhkan dari jaringan/kelompok lamanya.

Setelah napiter dinyatakan bebas dan kembali kemasyarakat, maka program deradikalisasi luar lapas mulai dilakukan oleh BNPT. Seperti pada program dalam lapas, deradikalisasi luar lapas juga diawali dengan tahap identifikasi. Tahap identifikasi tercantum dalam PP Nomor 77 Tahun 2019 Pasal 52 yang mengatakan bahwa identifikasi dan penilaian bagi mantan narapidana terorisme dilakukan dalam jangka waktu paling lama 30 (tiga puluh) hari terhitung sejak selesai menjalani pidana. BNPT harus melakukan identifikasi kepana eks napiter seperti identitas, tingkat keterpaparan, hasil pengembangan program deradikalisasi dalam lapas, kecenderungan untuk bergabung terhadap kelompok lamanya atau melakukan aksi terorisme kembali, dan memberikan rekomendasi untuk tahapan deradikalisasi selanjutnya. Faktor wilayah eks napiter ketika kembali, menjadi pertimbangan dalam melakukan identifikasi dan penilaian. Narasumber penulis mengatakan, semisal eks napiter tersebut kembali ke wilayah yang lingkungannya tidak aware dan tidak merangkulnya, kemungkinan eks napiter tersebut untuk "kembali" lagi ke jaringan/kelompoknya sangat terbuka lebar. Berbeda dengan lingkungan yang sangat guyub, warganya aware, ramah, pasti eks napiter tersebut merasa diperhatikan dan kemungkinan untuk "kembali" akan lebih kecil.

Tahap pembinaan kewirausahaan menjadi jalan masuk pertama yang dilakukan oleh BNPT dalam melakukan penggalangan kepada eks napiter. Alasan kenapa pembinaan kewirausahaan harus menjadi langkah awal sesuai dengan teori 3N (Needs, Narratives, Networks) dari Kruglanski, Belanger, dan Gunaratna (2019). Needs adalah yang berkaitan dengan kebutuhan hidup eks napiter. Pembinaan kewirausahaan memiliki tujuan untuk membantu membina dan mendampingi eks napiter dalam kebutuhan hidup eks napiter. Setelah itu Narratives adalah hal yang berkaitan dengan literasi eks napiter. Setelah apa yang dibutuhkan terpenuhi, mulai jauhkan dari narasi dan bacaan mengenai pemahaman lamanya. Terakhir adalah networks, dimana eks napiter harus dijauhkan dari jaringannya dan tidak diperbolehkan menghubungi kembali.

Dalam melakukan pembinaan kewirausahaan, BNPT banyak memberikan modal kepada eks napiter untuk mengembangkan usahanya seperti beternak, berkebun, membuka reparasi, bengkel, warung makan, dan lain-lain. Modal yang diberikan BNPT tidak hanya dalam bentuk uang, bentuk lain seperti akses, bantuan izin, pelatihan kerja, proposal untuk membangun usaha. Jadi bantuan yang diberikan oleh BNPT adalah mindset, asset, dan jaringan dalam berwirausaha. Kemudian, hubungan yang dibangun antara BNPT dan eks napiter adalah hubungan yang sifatnya adalah mitra, dan dibuat setara, tidak ada yang lebih tinggi dan tidak ada yang lebih rendah. Hubungan yang bersifat mitra inilah yang mampu memunculkan timbal balik antara BNPT dengan eks napiter. Seperti dicontohkan oleh narasumber penulis, eks napiter di Poso kelompok dari Ustadz Yasin, Arifudin Lako, dan Upik Pagar dibantu oleh BNPT untuk membentuk peternakan ayam dengan catatan tidak boleh kembali ke jaringan lamanya. 
Tahap selanjutnya adalah tahapan pembinaan wawasan kebangsaan. Dalam tahapan ini BNPT menggandeng seluruh elemen masyarakat untuk ikut membantu membina eks napiter dalam memahami soal kebhinekaan dan Pancasila. Idris (2017) menjelaskan, dalam melakukan pembinaan wawasan kebangsaan kepada eks napiter diperlukan materi-materi yang disesuaikan dengan latar belakang budaya asal eks napiter. Seperti pembinaan wawasan kebangsaan yang dilakukan kepada eks napiter yang berasal dari Poso dan Ambon, titik beratnya pada mewujudkan kehidupan yang harmonis antar suku, agama, dan RAS, karena menimbang latar belakang daerah tersebut pernah terjadi konflik berbasis SARA. Kemudian berbeda ketika melakukan pendekatan kepada eks napiter yang berasal dari Aceh, titik beratnya pada penguatan Pancasila sila ketiga yaitu Persatuan Indonesia, supaya tidak lagi muncul benihbenih radikal separatisme.

Selain itu dalam pembinaan wawasan kebangsaan, narasumber penulis menceritakan bahwa dia pernah membantu dan mendampingi salah satu eks napiter bernama Yudi Zulfachri untuk melanjutkan S2 nya karena dia memiliki kesukaan dan keahlian dalam hal belajar. Yudi Zulfachri merupakan eks napiter alumni dari Institut Pemerintahan Dalam Negeri (IPDN) yang pernah terlibat dalam kelompok Jamaah Ansharut Daulah (JAD). Yudi berhasil dibina dan didampingi melanjutkan S2nya di Program Studi Kajian Ketahanan Nasional, Universitas Indonesia paska bebas dari penjara. Pembinaan wawasan kebangsaan yang bersifat administratif juga dilakukan oleh BNPT seperti membantu eks napiter untuk mendapatkan KTP dan SIM. Hal tersebut dibutuhkan oleh eks napiter supaya mereka tidak kesulitan ketika akan mengurus administrasi seperti pembukaan rekening bank dan BPJS. Bagi BNPT, dengan adanya keinginan eks napiter untuk membuat KTP dan SIM mampu membuat mereka menjadi patuh terhadap hukum Indonesia dan BNPT dapat melakukan monitoring terhadap aktivitas yang menggunakan KTP dan SIM.

Tahap terakhir adalah tahapan pembinaan wawasan keagamaan. Tahapan ini merupakan tujuan utama dari program deradikalisasi BNPT. Seluruh program yang dilakukan oleh BNPT memiliki substansi untuk mengubah pemahaman dan cara pandang eks napiter terhadap Agama. Kegiatan pembinaan wawasan keagamaan yang diajarkan adalah materi-materi mengenai kerangka persatuan dan kerukunan setiap umat beragama di Indonesia. Dalam membina keagamaan eks napiter, biasanya dilakukan dengan cara menemui person to person dan diajak untuk berdiskusi. Selain itu BNPT juga mengajak para tokoh agama yang berasal dari organisasi masyarakat moderat seperti Majelis Ulama Indonesia, Nahdlatul Ulama, dan Muhammadiyah. Pada bulan Desember tahun 2013, BNPT juga pernah mendatangkan ulama asal Yordania bernama Syekh Ali Hasan al-Halabi dan ulama Mesir bernama Syekh Hisyam an-Najjar dan Syekh Najib Ibrahim, mereka merupakan mantan tokoh dari Jamaah Islamiyah Mesir pada tahun 1970an dan 1980an yang mana fatwanya pada jaman dahulu sering digunakan oleh para pelaku teror untuk melakukan aksi hingga saat ini (Khamdan, 2015). Kemudian BNPT juga sering mengajak eks napiter yang sudah sadar dan dianggap sebagai pemimpin mereka seperti Ali Imron dan Umar Patek untuk memberikan wawasan keagamaan kepada mereka tentang pemaknaan jihad yang salah.

Dalam melakukan program deradikalisasi, negara harus selalu hadir dalam pendampingan dan pembinaan kepada mantan napiter karena jika negara abai, tidak menutup kemungkinan para eks napiter tersebut akan merasa tidak diperahatikan dan kembali kedalam jaringannya dan menjadi radikal. Agar tidak terjadi distorsi pemahaman dan distorsi aplikasi terhadap kearifan lokal masyarakat Indonesia, diperlukan penanaman kembali nilai tentang keagamaan yang disesuaikan dengan konteks Indonesia (Idris, 2017).

\section{Analisis Penggalangan Intelijen dalam Program Deradikalisasi}

Program deradikalisasi adalah sebuah program yang mengedepankan nilai-nilai pencegahan daripada penindakan. Nuansa psikologis, sosial, dan budaya menjadi sangat kental dalam menjalankan program ini, karena tujuannya adalah berupaya untuk mengubah cara pandang para napiter dan eks napiter kepada jalan yang benar dan tidak kembali berfikiran radikal. Program seperti 
identifikasi, pendampingan, pembinaan, dan pemberdayaan yang dilakukan dalam program deradikalisasi merupakan bahasabahasa penggalangan intelijen, "nafas" dan tujuannya sama yaitu menguasai ESTOM target. Metode dalam penggalangan intelijen yang akan menjadi analisis penelitian ini adalah metode RASCLS dan MICE (Reciprocation, Authority, Scarcity, Liking, Social proof, dan Money, Ideology, Coercion, dan Ego).

Metode reciprocation merupakan sebuah metode yang menggunakan pendekatan dengan menyentuh hati sasaran dengan selalu berbuat baik secara intens sehingga sasaran merasa untuk harus membalas apa yang sudah diberikan kepadanya (Cialdini, 2007). Metode ini merupakan langkah awal yang dilakukan oleh penggalang supaya dapat melakukan intervensi lanjutan sesuai dengan kehendak dari penggalang (Burkett, 2013). Dalam program deradikalisasi, metode reciprocation digunakan sebagai pintu masuk penggalang sebelum melakukan program lanjutan seperti pembinaan dan pendampingan kepada napiter dan eks napiter. Terdapat beberapa contoh metode reciprocation yang digunakan oleh petugas BNPT dalam melakukan penggalangan kepada napiter/eks napiter seperti, pertama BNPT menempatkan eks napiter sebagai mitra, dan bukan sebagai eks napiter. Hal tersebut dilakukan untuk membuat kesetaraan antara BNPT dengan eks napiter sehingga reciprocal connectivity dapat dilakukan secara maksimal. Kedua, membantu pembuatan KTP dan SIM kepada eks napiter dengan timbal balik seperti memudahkan untuk menguruh BPJS dan membuka rekening bank, eks napiter menjadi taat hukum, dan pergerakannya terekam. Ketiga, jika terdapat kasus eks napiter yang ditolak masyarakat, BNPT membantu untuk mencarikan rumah/kontrakan yang lingkungannya sudah disetting kondusif dengan melibatkan tokohtokoh lokal yang moderat. Sehingga eks napiter merasa diterima dilingkungan baru dan perlahan akan meninggalkan paham radikal lamanya.

Metode authority merupakan sebuah pendekatan dengan menggunakan otoritas yang dipatuhi oleh target, karena setiap orang sejak kecil sudah diajarkan untuk patuh terhadap otoritas tertentu (Burkett,
2013). Metode ini sangat menguntungkan BNPT karena dengan menggunakan metode authority dalam menggalang, para eks napiter pasti secara perlahan akan mengikuti kehendak otoritas yang didatangkan karena tidak ingin mendapat "hukuman". Metode authority digunakan dalam progam deradikalisasi dalam lapas dan luar lapas. Narasumber penulis mengatakan, jika bertemu dengan napiter yang keras, BNPT akan menggunakan napiter/eks napiter lain yang sudah sadar dan memiliki "pangkat" lebih tinggi untuk membantu mendekati dan menyadarkan napiter yang masih keras. Contohnya adalah seperti eks napiter yang bernama Yudi Zulfachri mantan anak buah Aman Abdurrahman. Ketika masih didalam penjara Yudi hanya mau menerima masukan dari Ali Imron karena dia menganggap Ali Imron memiliki pangkat dan ilmu yang jauh lebih tinggi daripada dirinya. Metode ini sangat berguna dalam melakukan deradikalisasi karena dalam kultur jaringan kelompok teroris, mereka memegang prinsip sami'na wa atho'na kepada orang yang memiliki pangkat lebih tinggi.

Metode scarcity merupakan sebuah pendekatan dengan membuat target menjadi terdesak, kesusahan, dan kelangkaan sehingga mau tidak mau dia akan memilih tawaran dari penggalang (Burkett, 2013). Menurut narasumber penulis, metode ini tidak dilakukan dalam program deradikalisasi karena tujuan deradikalisasi adalah melakukan pembinaan, pendampingan, dan pemberdayaan bukan untuk melakukan kesusahan kepada target (napiter/eksnapiter).

Metode commitment merupakan sebuah pendekatan dengan memberikan dorongan kepada target untuk membuat komitmen dengan penggalang atas konsistensinya (Burkett, 2013). Bentuk komitmen yang dilakukan seperti berbagi data dan melakukan kerja sama sehingga dapat berkelanjutan. Salah satu bentuk metode komitmen yang dilakukan BNPT dengan pertimbangan lembaga lain seperti BIN dan Densus 88 Polri adalah dengan mengabulkan permintaan Umar Patek dengan menjadikan istrinya sebagai WNI pada tahun 2019. Metode tersebut dilakukan berdasarkan hasil assessment dari Umar Patek yang memiliki sikap, komitmen, dan konsistensi untuk kembali pada NKRI dan ikut membantu 
program deradikalisasi yang dilakukan oleh BNPT.

Metode liking, merupakan sebuah pendekatan dengan menggunakan persamaan, kesukaan, daya tarik, dan pujian kepada target (Cialdini, 2007). Supaya penggalang dapat mudah melakukan intervensi kepada target adalah dengan mengetahui kesamaan dan kesukaan karena penggalang dapat mengerti kelemahan dan celah target yang akan diintervensi (Burkett, 2013). Tujuan akhirnya adalah membuat hubungan antara penggalang dengan target dari lawan menjadi kawan dan orang kepercayaan. Metode ini banyak digunakan ketika melakukan tahapan pembinaan kewirausahaan. Seperti program kewirausahaan yang mengarahkan dan membantu napiter/eks napiter untuk menjalankan sesuai passion nya, napiter/eks napiter yang menyukai bidang pertanian diarahkan untuk beternak dan berkebun; yang menyukai ketrampilan diarahkan untuk membuka bengkel, reparasi, menjahit; yang suka kuliner diarahkan membuka warung makan. Selain itu dalam pembinaan, BNPT juga menggunakan persamaan atas suku dan bahasa dari target untuk memudahkan dalam berkomunikasi dan melakukan intervensi ketika sedang menjalankan program deradikalisasi.

Metode social proof merupakan pendekatan dengan menunjukkan pembuktian sosial kepada target atas "perilaku yang benar" dari lingkungan sosialnya (Burkett, 2013). Metode ini dilakukan ketika menemukan napiter/eks napiter yang masih keras dan sulit untuk didekati. Karena terkadang petugas BNPT maupun petugas lainnya akan dianggap kafir dan thogut. Maka BNPT menggunakan teman-teman dari target tersebut yang sudah sadar dan kembali ke NKRI untuk membantu mendekati serta menyadarkan target tersebut.

Metode money merupakan pendekatan dengan menggunakan uang. Penggunaan uang dalam penggalangan merupakan cara klasik untuk memudahkan penggalang dalam menguasai ESTOM target. Dalam program deradikalisasi, metode money digunakan namun tidak semata-mata hanya memberikan uang kepada eks napiter, melainkan harus ada prosesnya terlebih dahulu. Salah satu contohnya adalah dengan menggunakan mitra deradikalisasi BNPT didaerah seperti Yayasan Gema Salam. BNPT memberikan bantuan dalam bentuk "pancing" dan "kail" nya, seperti membantu Yayasan Gema Salam dalam pengajuan proposal untuk usaha eks napiter kepada Kemensos dan akhirnya diberikan uang tunai 5 Juta hingga 15 Juta. Selain itu BNPT juga membantu Yayasan Gema Salam dalam program yang bernama "wareg". Program tersebut memiliki tujuan agar eks napiter kenyang dalam bentuk bantuan pekerjaan dan keuangan.

Metode ideology merupakan pendekatan dengan menggunakan ideologi sebagai sebuah motivasi untuk mengekspresikan nilai dan keyakinan dari target secara sadar maupun tidak sadar (Charney \& Irvin, 2016). Metode ini digunakan oleh BNPT ketika menjalankan program pembinaan wawasan keagamaan. BNPT menggunakan ormas Islam yang moderat untuk membantu mengajak diskusi kepada napiter/eks napiter untuk menyentuh sisi ideologinya. Selain dengan menggunakan diskusi, program berbentuk fisik dengan metode ideology seperti ketika BNPT meresmikan pendirian Masjid dan Taman Pendidikan Al-Quran Baitul Muttaqien di kampung halaman Amrozi dan menjadikan masjid tersebut sebagai pusat dakwa Islam moderat (Republika, 2017).

Metode coercion merupakan sebuah pendekatan dengan menggunakan pemaksaan, pemerasan, dan penyiksaan kepada target dalam melakukan sebuah penggalangan. Dalam program deradikalisasi, metode coercion tidak digunakan karena metode ini tidak bersifat membina, mendampingi, dan memberdayakan eks napiter, malah cenderung menyusahkan. Metode ini merupakan pendekatan negatif karena unsur kekerasan lebih ditonjolkan daripada unsur kelembutan/soft. Sedangkan dalam program deradikalisasi, tujuannya adalah pendekatan hati ke hati.

Metode ego merupakan sebuah pendekatan dengan menunjukkan prinsip realitas untuk melakukan toleransi terhadap konsep tentang diri (Burkett, 2013). Metode dengan menggunakan prinsip ego dilakukan dengan mengajak keluarga napiter untuk membantu menyadarkan napiter yang masih keras dan sulit didekati. Contohnya adalah 
eks napiter bernama Thomas Muslimin Hasibuan, seorang mantan teroris yang tertangkap pada tahun 2013 kasus perampokan/fa'I Bank CIMB Niaga Medan yang tersentuh ego nya ketika masih dipenjara karena faktor keluarga. Thomas yang ditahan di Lapas Sentul, Bogor akhirnya sadar ketika saat dikunjungi oleh keluarga dan anaknya, namun sang anak tidak mengenali Thomas sebagai ayahnya, dan ketika digendong anaknya justru menangis (Habibie, 2018). Dengan adanya peristiwa tersebut, Thomas akhirnya melepaskan ego lamanya dengan meninggalkan ideologi radikal dan menjauh dari kelompok lamanya, karena paska bebas dia menyadari bahwa harus menjadi kepala keluarga dan menjadi sosok "ayah" dari anak-anaknya.

Berdasarkan teori dari Horgan (2008) yang mengatakan bahwa deradikalisasi dilakukan dalam dua komponen yaitu behavioral disengagement (penghentian fisik) dan psychological disengagement (Perubahan sikap). Hal tersebut sangat relevan dengan metode penggalangan intelijen yang juga menyasar pada penguasaan secara Fisik dan psikologis melalui ESTOM (Emosi, Sikap, Tingkah laku, Opini, Motivasi) sasaran pengalangan. Karena sasaran penggalangan adalah manusia dan napiter/eks napiter memiliki akal budi dan perasaan maka metode yang digunakan adalah penguasaan kepada psikologi manusia.

\section{Kesimpulan}

Berdasarkan hasil pembahasan dan analisis yang telah dijelaskan sebelumnya, dapat diberikan kesimpulan bahwa dalam menjalankan program deradikalisasi, BNPT menggunakan metode penggalangan intelijen dengan teknik RASCLS dan MICE. Dalam RASCLS dan MICE, program deradikalisasi tidak menggunakan metode Scarcity dan Coercion karena tujuan dari deradikalisasi adalah membina, mendampingi, dan memberdayakan napiter dan eks napiter. Metode penggalangan yang dilakukan oleh BNPT dalam program deradikalisasi menggunakan pendekatan lunak atau soft approach karena yang dituju adalah hati dari napiter/eks napiter.

Metode penggalangan ini diharapkan dapat menjadi referensi bagi BNPT dalam melakukan deradikalisasi dengan catatan harus dilakukan secara konsisten dan intensif. Karena metode penggalangan yang disentuh adalah hati seseorang, yang mana sebuah "barang" tidak terlihat. Sehingga membutuhkan waktu yang lama supaya bisa untuk mengubah ESTOM nya untuk mengikuti kehendak penggalang. Selain itu perlunya peningkatan koordinasi antar lembaga dan mitra BNPT di daerah supaya program yang dilakukan tepat sasaran dan tidak saling tumpang tindih antar instansi.

\section{Referensi}

Burkett, Randy. (2013). An Alternative Framework for Agent Recruitment: From MICE to RASCLS. Studies in Intelligence Vol 57, No 1.

Charney, David L., dan Irvin, John A. (2016). The Psychology of Espionage. Intelligencer. Journal of U.S. Intelligence Studies Vol 22, No 1.

Cialdini, Robert B. (2007). Influence, The Psychology of Persuasion. HarerCollins ebooks.

Dirgantara, A. (2021). Polri: 94 Terduga Teroris Ditangkap Sejak Januari 2021. Detiknews.

https://news.detik.com/berita/d5514469/polri-94-terduga-terorisditangkap-sejak-januari-2021

Febriyansah, MN., Khodriah, L., Wardana, RK. (2018). Upaya Deradikalisasi Narapidana Terorisme di Lembaga Pemasyarakatan (Lapas) Kedung Pane Semarang. Seminar Nasional Hukum Universitas Negeri Semarang, Vol 3, No 1.

Golose, Petrus Reinhard. (2009). Deradikalisasi Terorisme: Humanis, Soul Approach dan Menyentuh Akar Rumput. Jakarta. Penerbit Yayasan Pengembangan Kajian Ilmu Kepolisian.

Idris, Irfan. (2017). Membumikan Deradikalisasi: Soft Approach Model Pembinaan Terorisme Dari Hulu Ke Hilir Secara Berkesinambungan. Jakarta. Penerbit Daulat Press.

Indrawan, J., \& Aji, M P. (2019). Efektivitas Program Deradikalisasi Badan Nasional Penanggulangan Terorisme Terhadap Narapidana Terorisme di Indonesia. Jurnal Pertahanan \& Bela Negara, Vol 9, No 2.

Khamdan, Muh. (2015). RETHINKING DERADIKALISASI: Konstruksi Bina Damai 
Penanganan Terorisme. ADDIN, Vol 9, No 1.

Kruglanski, A.W., Belanger, J.J., Gunaratna, R. (2019). The Three Pillars of Radicalization: Needs, Narratives, and Networks. Oxford University Press.

Habibie, N. (2018). Cerita Eks Napiter di Medan, Tobat Usai Tak Dikenali Buah Hati. Merdeka.com.

https://www.merdeka.com/peristiwa/ce rita-eks-napiter-di-medan-tobat-usai-takdikenali-buah-hati.html

Moghaddam, Fathali M. (2005). The Staircase to Terrorism. American Psychologist Association, Vol 60, No 22. Hal 161-169.

Neumann, Peter R. (2010). Prisons and Terrorism; Radicalisation and Deradicalisation in 15 Countries. International Centre for the Study of Radicalisation and Political Violence, London.

Penaflor, E.H. (2012). Spies Like Us: A Comparison of Infiltrating Networked Terrorist Organizations Versus Foreign Intelligence Services. San Diego University: Master of Science in Homeland Security.

Pickering, Richard. (2014). Terrorism, Extremism, Radicalisation and the Offender Management System in England and Wales, in Andrew Silke (Ed). Prisons, Terrorism, and Extremism: Critical Issues in Management, Radicalisation and Reform. Routledge, Oxon.

Porges, Marisa. (2014). Saudi Arabia's "Soft" Approach to Terrorist Prisoners, in Andrew Silke (Ed). Prisons, Terrorism, and Extremism: Critical Issues in Management, Radicalisation and Reform. Routledge, Oxon.

Prunckun, Hank. (2010). Handbook of Scientific Methods of Inquiry for Intelligence Analysis. UK. The Scarecrow Press.

Purwanto, Wawan H. (2012). Satu Dasawarsa Terorisme di Indonesia. Jakarta. CMB Pess.

Ramadhan, B. (2017). BNPT Resmikan Masjid di Kampung Halaman Amrozi. Republika.id. https://nasional.republika.co.id/berita/n asional/hukum/17/07/22/otgd6w330bnpt-resmikan-masjid-di-kampunghalaman-amrozi
Robingatun. (2017). Radikalisme Islam dan Ancaman Kebangsaan. Jurnal Empirisma Vol 26, No 1. 97-106.

Saronto, Y Wahyu. (2018). Intelijen: Teori Intelijen dan Pembangunan Jaringan. Yogyakarta. Penerbit ANDI.

Suarda, I Gede Widhiana. (2016). A Literature Review on Indonesia's Deradicalization Program For Terrorist Prisoners. Jurnal MIMBAR HUKUM, Vol 28, No 3. Hal 526543.

Sukarno, Irawan. (2011). Aku "Tiada" $A k u$ Niscaya, Menyingkap Lapis Kabut Intelijen. Jakarta. Yayasan Pustaka Obor Jakarta.

Surya Bakti, Agus. (2014). Darurat Terorisme: Kebijakan Penegahan, Perlindungan, dan Deradikalisasi. Jakarta. Penerbit Daulat Press.

Adyatama, E. (2020). Mabes Polri: Ada 228 Penangkapan Terorisme Sepanjang 2020. Wibowo E.A. (Editor). Tempo.co. https://nasional.tempo.co/read/141667 9/mabes-polri-ada-228-penangkapanterorisme-sepanjang-2020

Wahid Foundation \& CSIS. (2017). Intoleransi dan Radikalisme Di Kalangan Perempuan. 